\title{
Ainu Language
}

National Cancer Institute

\section{Source}

National Cancer Institute. Ainu Language. NCI Thesaurus. Code C153829.

A language spoken by members of the Ainu ethnic group on the northern Japanese island of Hokkaido. It has no generally accepted genealogical relationship to any other language family. 